\title{
Revisiting Missile Defense of the United States: Contending Arguments and Security Implications for the Republic of Korea*
}

\author{
Ko, Bong-Jun \\ (Jeju Peace Institute)
}

〈CONTENTS〉

I. Introduction

II. Is the missile defense defensive or offensive?

III. Rogue states' threats are real?

IV. Can it shoot down missiles?
$V$. Does it make the world more safe or reduce the possibility of war occurring?

VI. Concluding remarks: Should we have an MD?

- Keyword: U.S. MD, security dilemma, rogue states, the feasibility of MD, regional stability in Northeast Asia

\section{【ABSTRACT】}

The United States has pursued a missile defense (MD) capability until recently without a serious challenge against it. However, other great powers are beginning to respond to it by strengthening their strategic offensive weapons. Now, it seems that a new arms race is inevitable in Northeast Asia and the Pacific. In this situation, a good grasp of contending issues regarding U.S. MD is essential for our national security. By asking four critical questions about U.S. MD, this study clarifies possible effects of U.S. MD on our national security. To maintain peace and stability on the Korean Peninsula and in the region, and to avoid any unwanted outcome, we need to conduct more thorough analyses of international and regional dynamics that would be induced by MD systems.

*I would like to express my gratitude to those who provided comments on or suggestions for this paper, especially Seong-Woo Yi and Douglas J. Hansen. I also appreciate critiques by three anonymous referees. 


\section{I . Introduction}

The United States has pursued a missile defense (MD) capability. Facing no peer competitor who can directly challenge U.S. exploitation of international opportunities, the U.S. began the active deployment of the system after the effective domestic veto had dissolved by way of the Republican full control over both executive and legislative branches as a result of the 2000 presidential election." Although the 2006 midterm elections resulted in a Democratic majority in both Houses, it appears that this alone cannot divert the existing U.S. commitment to MD and establish a new consensus for different policy choices. ${ }^{2)}$

Until recently, U.S. primacy in the strategic balance seemed to shape for the first time in the nuclear age." The U.S.'s pursuit of MD has yet to face a tangible opposition, since MD is one of the most significant strategic challenges for other great powers to respond to in the coming years after the probable conclusion of the U.S.-led war on terrorism. In fact, other great powers are beginning to respond to it by strengthening their strategic offensive weapons. The well-known security dilemma is at work, and U.S. MD is in the center of that dynamic.

Since the U.S. and its potential adversaries are surrounding Northeast Asia and the

1) Before the current Bush program, there were five attempts by the United States to develop MD. My preliminary research shows that when U.S. interest in MD was high, both domestic policy consensus and international incentives were present at the same time. Based on this assessment, I suppose that international incentives and domestic policy consensus have been the two necessary conditions for U.S. MD. However, discussions on U.S. domestic consensus for MD are restricted to the minimum in this paper for the sake of clear discussions on the international implication of U.S. MD.

2) I assume that in U.S. politics, a unified government has a policy consensus in the sense that it reduces the number of effective vetoes to almost zero regarding critical policy issues. For a discussion on the role and effect of veto players in decision-making, see George Tsebelis, Veto Players: How Political Institutions Work (Princeton: Princeton University Press, 2002). In this vein, to change the decision for MD deployment made by the previous policy consensus, the U.S. should achieve a new policy consensus through proper dealing with possible vetoes. For a similar argument regarding general policy decision in a political system, see Stephen Haggard and Mathew D. McCubbins, "Political Institutions and the Determinants of Public Policy," in Haggard and McCubbins (eds.), Presidents, Parliaments, and Policy (Cambridge: Cambridge University Press, 2001), p.12.

3) Regarding this, Lieber and Press argue that the U.S. is currently achieving nuclear primacy. Russia's strategic weapons upgrade projects have been much delayed, and Chinese strategic weapons modernization plans have been too slow to make any impact on the U.S. deployment of MD. See Keir A. Lieber and Daryl G. Press, "The Rise of U.S. Nuclear Primacy," Foreign Affairs 85-2 (March/April 2006), pp.42-55; and Lieber and Press, "The End of MAD? The Nuclear Dimension of U.S. Primacy," International Security 30-4 (Spring 2006), pp.7-44. 
Pacific Ocean, it seems that a new arms race relating to U.S. MD is inevitable in this region. In this situation, a good grasp of contending issues regarding the U.S. MD is necessary to understand the security dynamic and conditions of stability in the region. By answering four critical questions related to the U.S. MD, this paper tries to clarify the implication of MD for our national security.

In the following section, I will discuss competing interpretations of the nature of U.S. MD. I argue that although it is optimized for defense, the U.S. MD can be offensive to both Russia and China in the sense that it destabilizes the strategic balance in favor of the U.S. by weakening two countries' deterrence capabilities. Next, I will address the rogue states' threats which constitute the rationale behind the U.S. decision for MD and maintain that the threats are real but considerably exaggerated and that we should establish our own rationale when we consider a possibility for developing MD capabilities. Then, I will examine the feasibility of the current MD systems and claim that despite the technological probability, the systems under development are not reliable enough for us to risk dangers that would be produced by our decision to have MD capabilities. Finally, I will review broader implications of U.S. MD regarding regional stability in Northeast Asia. MD may be counterproductive if its international implications are not fully considered. In conclusion, I argue that we need to conduct more thorough analyses of international and regional dynamics that would be induced by our MD systems.

\section{Is the missile defense defensive or offensive?}

Both, depending on different viewpoints. These competing interpretations of the system reiterate the significance of the security dilemma in international relations. The implication of the security dilemma is that under self-help international anarchy, steps (mostly strengthening military capabilities or forming alliance) taken by one state to increase its own security often make other states more insecure. The response (in kind) of these states in turn threatens the first state and may leave everyone worse off than at the start. ${ }^{4)}$ Proponents of MD argue that MD is an essential defense measure for the U.S. under changing international environments. Some others do not see it in that way, arguing that U.S. MD threatens their security; therefore, it is offensive.

The Bush administration has emphasized that the current system in development is

4) For an excellent discussion of the security dilemma, see, among others, Robert Jervis, “Cooperation under the Security Dilemma," World Politics 30-2 (1978), pp.167-214. 
purely defensive, arguing that the system is designed to shoot down incoming missiles heading for targets in the U.S. and U.S. allies. MD proponents maintain that missile developments in some states of concern (SOCs) are the main factor for making the move toward the development of the current MD system. This threat argument insists that such a defense is in its nature not threatening others. It is designed neither to change the status quo nor to expand U.S. power, but is only a response to new threats. ${ }^{5)}$ In IR literature, more often than not, external threats are assumed to play an important role in bringing on states' substantial policy choices, usually in the form of a military buildup or alliance commitment. $\left.{ }^{6}\right)$ Countering opposing power concentrations or threats is assumed to be a natural behavior of a state under international anarchy.

As such, the Bush administration has asserted that the U.S. must have a defense against long-range missiles for two reasons. First, there is a great likelihood that SOCs will attempt to attack the U.S. by long-range nuclear missiles. ${ }^{7)}$ Second, the U.S. currently has no option to avoid such an attack. With their strong motivation to change the status quo, the SOCs may rely on nuclear threats or actually initiate a nuclear war, and the U.S. should not count on a traditional way of deterrence.

This is a plausible argument, but a counterargument is in order. According to offensive realism, great powers are compelled to seek more power whenever possible. ${ }^{8)}$ In other words, power-seeking is a natural tendency of a state under international anarchy. In line with this understanding, the U.S. currently seems to be trying to reduce its vulnerability to uncertain future threats by preventing opponents from challenging it while utilizing global projection of its military force if necessary, thus maximizing its security and power of various functions. ${ }^{9)}$ With the existing U.S. deterrence capabilities, added strategic defense capabilities position the U.S. well over other great powers. This may be the most desirable situation the U.S. has ever imagined. The U.S. now has the best opportunity to create this situation.

5) For example, see White House, "Remarks by the president on National Missile Defense" (December 13, 2001) http://www.whitehouse.gov/news/releases/2001/12/20011213-4.html (September 10, 2007).

6) See Kenneth Waltz, Theory of International Politics (Reading, MA: Addison-Wesley, 1979), chap. 8.

7) U.S. Department of Defense, Nuclear Posture Review of 2001 and White House, The National Security Strategy of the United States of America (September 2002).

8) For offensive realism, see, among others, John J. Mearsheimer, The Tragedy of Great Power Politics (New York: Norton, 2001).

9) For an excellent discussion regarding the utility and different functions of military power, other than actual offense, see Robert J. Art, “To What Ends Military Power," International Security 4-4 (Spring 1980), pp.3-35. 
Actually the balance of power between the U.S. and its potential adversary has constantly shifted in favor of the U.S. Both the U.S. and Russia have gradually reduced the number of strategic nuclear warheads based on the START II agreement and negotiation in START III talks. Despite this reduction, Russia still possesses large quantities of strategic weapons that can inflict unacceptable damage to the U.S. However, the U.S. has an edge in quantities, and MD with some changes in the strategic weapons systems and procurement in the two countries would make a significant difference in the strategic balance between the two. ${ }^{10}$

First of all, Russian ICBM forces, which are the traditional backbone of its strategic forces, have been continuously reduced. As long as the Russian ICBM share of total strategic forces remains large, the reduction should have a greater impact on its overall strategic power than the same kind of reduction may have on the overall U.S. strategic forces. This waning Russian ICBM capability is a serious disadvantage for Russia considering the fact that the modernization of Russian submarine forces as another element of its nuclear triad has been long delayed, and until recently the retirement of Russian strategic submarines has continued without replacements. ${ }^{11}$

Second, the operational capability of the Russian strategic submarine is in doubt. Russia conducted only 8 nuclear submarine deterrent patrols from 2002 through 2005, while it did 61 patrols in 1990 alone. ${ }^{12}$ For these reasons, some studies argue that the U.S. achievement of a first-strike capability is beginning. According to these studies, most Russian strategic nuclear forces are not ready for use and are vulnerable to a U.S. surprise attack, whereas the U.S. has modernized its strategic weapons by making them more accurate and powerful (Lieber and Press, 2006a \& b).

In short, against U.S. MD, Russia should be less confident now than in the past although it still possesses a deterrence capability. Now the U.S. has more effective and less vulnerable (to opponent's first strike) nuclear forces, and more importantly, if the U.S. launches a surprise strike on Russia, there will be no guarantee that Russia is able to protect its second-strike capabilities that can inflict unacceptable damage to a U.S. protected by MD.

10) In terms of economic power, Russia is no longer a country that can interrupt any probable U.S. power maximization interest. For example, during the early 2000s, Russia could only allocate less than $5 \%$ of U.S. military expenditure to its military. See The Stockholm International Peace Research Institute, The SIPRI Military Expenditure Database. http://first.sipri.org/non_first/milex.php (September 10, 2007).

11) Robert S. Norris and Hans M. Kristensen, "Russian Nuclear Forces, 2005," Bulletin of the Atomic Scientists 61-2 (March/April 2005), pp.70-72.

12) Robert S. Norris and Hans M. Kristensen, "Russian Nuclear Forces, 2006," Bulletin of the Atomic Scientists 62-2 (March/April 2006), p.67. 
In addition, to China, U.S. MD is also very offensive. The Clinton administration was initially preparing an MD system with 100 interceptors. In theory, to defend against a few arsenals from SOCs, 100 interceptors may be enough. However, the Bush administration is expanding the interceptor numbers as well as their range of coverage. Considering the fact that China has maintained only about 20 ICBMs that are capable of targeting the entire continental U.S., even 100 interceptors are enough to deploy an effective shield against a Chinese nuclear attack. ${ }^{13)}$ However, the U.S. is increasing the system's capacity aiming at making the system able to engage all classes and ranges of ballistic missiles. Under this situation, in a nuclear exchange with the U.S., China will have no second-strike capability. ${ }^{14)}$ This means that U.S. MD entails a very serious strategic disadvantage on China vis-à-vis the U.S. ${ }^{15)}$

Overall, although MD is designed to destroy attacking missiles, the U.S. MD is regarded as offensive by both Russia and China in the sense that it destabilizes the strategic balance in favor of the U.S. by weakening two countries' deterrence capabilities. In this sense, since a simple distinction between offensive and defensive weapons does not make a sense, MD is likely to intensify the effect of the security

13) The meaning of the number of interceptors is very suggestive. Since each attempt of interception of an incoming missile is independent of any previous attempts, the probability of intercept remains the same throughout each attempt. Therefore, if $q$ is the probability of failure, the probability of a successful interception of the missile at least once in $n$ tries is $1-q^{n}$. Technically, a successful interception is determined by three factors: the probability of discrimination of an actual warhead from decoys, the reliability of the rocket portion of interceptor, and the probability for hitting the warhead. To successfully intercept a missile, these three necessary conditions should be fulfilled at the same time. For a detailed discussion, see Craig Eisendrath, Melvin A. Goodman, and Gerald E. Marsh, The Phantom Defense: America's Pursuit of the Star Wars Illusion (Westport: Praeger, 2001). If we assume the three probabilities are $90 \%$ each, then the number of interceptors required for a $90 \%$ chance of stopping an attacking missile is 2 , and for $80 \%$ each, 3-4 interceptors are needed. Although Eisendrath, Goodman, and Marsh address a very pessimistic view about obtaining the discriminating technology at such a high percentage level, it is reasonable to assume that it is the U.S. expectation and will be available in the near future. In addition, the rocket reliability and hitting technology can be guaranteed at a more advanced level. If we assume the three probabilities to be $50 \%, 90 \%$, and $90 \%$, respectively, 4-5 interceptors are needed to warrant $90 \%$ chance of interception. In this sense, 100 interceptors are enough against Chinese ICBMs.

14) Since the U.S. has continuously improved its nuclear counterforce capabilities, China would feel great pressure to reduce the vulnerability of its own nuclear arsenal. See Keir A. Lieber and Daryl G. Press, "U.S. Nuclear Primacy and the Future of the Chinese Deterrent," China Security 3-1 (Winter 2007), pp.66-67.

15) Under this circumstance, China may not be able to contemplate a nuclear option against the U.S. in a probable crisis and have to limit the employment of its forces at the conventional level. See Lieber and Press (2007), p.68. 
dilemma unless other measures that prove non-revisionist intention of the U.S. or its allies are strongly presented. ${ }^{16)}$

\section{Rogue states' threats are real?}

Yes, and in fact, they have been growing. However, we should check the reality of the threats. The threats are real but may not be strong enough to justify the deployment of the U.S. MD.

Three things should be noted here regarding the threat argument. First of all, this threat perception comes from the conjecture that (even nuclear) deterrence does not work against the SOCs since they are not cost-sensitive like other normal states. Second, as Jervis puts it, one who believes that a situation is intolerable may feel strong psychological pressures to conclude that the situation should be changed before getting worse. ${ }^{17)}$ Finally, the proliferation of missile and nuclear technology makes rogue states' acquisition of nuclear missile capabilities much easier than in the past.

First, the "insensitivity" claim is based on the idea that SOCs or rogue states are revisionist and they would actually attack the U.S. in a self-destructive way. For example, Van Evera argues that nuclear deterrence does not work under certain conditions, if aggressor states are not cost-sensitive in terms of their citizens' lives and property. ${ }^{18)}$ He cites some examples of governments insensitive to their nations' suffering, including the mass killing under Stalin and Pol Pot, and the war initiation by Hitler and Saddam Hussein, etc.

By contrast, Waltz argues that rulers in the SOCs are sensitive to costs just like other rulers; thus we cannot expect that those rulers would risk more danger (nuclear retaliation), which would destroy a country that they want to continue to rule. ${ }^{19)}$ One issue here is that regardless of whether or not leaders care about their domestic constituencies, there is little or no benefit to initiate a nuclear attack. Why would those states strike the U.S. with ballistic missiles that are easily traceable, thus running the

16) See the discussion by Jervis (1978) on the balance and distinction between offense and defense.

17) See Robert Jervis, "The Political Effects of Nuclear Weapons: A Comment," International Security 13-2 (Fall 1988), p.89.

18) For this, see Stephen Van Evera, Causes of War: Power and the Roots of Conflict (Ithaca: Cornell University Press, 1999), pp.247-249.

19) See Kenneth Waltz, Peace, Stability, and Nuclear Weapons, Policy Paper 15, University of California Institute on Global Conflict and Cooperation (La Jolla, CA: IGCC, 1995), pp.6-7. 
risk of the whole thing at a "very little or nothing" game? In this regard, Mearsheimer and Walt also maintain that tyranny is not necessarily irrational, and therefore there is no reason that nuclear deterrence would not work against those states, especially given the condition that they do not have a second strike capability. ${ }^{20)}$

Second, there is a problem that by labeling SOCs as "rogue states," the probable danger associated with those actors is considerably exaggerated. The term "rogue" was originally used to denote countries of domestic oppression. ${ }^{21)}$ After several years' usage of this term, the U.S. State Department officially dropped the term, but the Bush administration began to reuse the term referring to several states. ${ }^{22}$ This labeling is misleading in two senses. First, the U.S. had similar experiences of this kind. During the early Cold War years, the U.S. strongly feared that the Soviet Union might use its nuclear weapons. The same fear emerged when China was about to deploy its ICBMs. ${ }^{23}$ In this respect, the rogue threats should be measured against those threats during the Cold War. In addition, as Mueller puts it, by labeling them, special attention was given to SOCs as if they constituted a new problem in international relations. They existed in the past and posed threats to the U.S. Now North Korea, for example, is far less significant a threat than during the Cold War because of its deteriorated economy and loss of external support from China and the USSR. Notwithstanding, North Korea is automatically assumed to be undeterrable, and its probable acquisition of weaponry is expected to reveal its offensive intention even though such use would be suicidal. ${ }^{24}$

Finally, making nuclear ICBMs is so difficult that only a few highly developed countries can possess the resources and technologies to make them work. ICBMs are very expensive to produce and maintain. There have been repeated U.S. governmental reports that emphasized the dangers of SOCs eventually obtaining a strategic nuclear strike capability, but the danger has never materialized. Although it appears that those states, especially both North Korea and Iran, are close to achieving the capability, there still remains doubt about the probability. Another related question is whether they will use the weapons. ${ }^{25)}$ If those actors really intend to inflict considerable damage on the

20) John J. Mearsheimer and Stephen M. Walt, “An Unnecessary War," Foreign Policy 134 (Jan/Feb 2003), pp.50-59.

21) Steven Mufson, "Threat of 'Rogue' States: Is It Reality or Rhetoric?" Washington Post (May 29, 2000), p.A01.

22) Michael W. Simon, "Rogue State Response to BMD: The Regional Context," Defense and Security Analysis 18-3 (2002), p.275.

23) James H. Lebovic, "The Law of Small Numbers: Deterrence and National Missile Defense," The Journal of Conflict Resolution 46-4 (August 2002), pp.458-459.

24) John Mueller, "Simplicity and Spook: Terrorism and the Dynamics of Threat Exaggeration," International Studies Perspectives 6-2 (May 2005), p.216. 
U.S., they should find better (cheap and easy) ways to do so (cruise missiles, suitcase bombs, and dirty bombs, etc). Actually, as Waltz notes, ICBMs are the least likely way SOCs would choose to deliver warheads. ${ }^{26)}$

These counterarguments suggest that rogue states' threats should be thoroughly reexamined. Their main purpose in building such weapons may be to gain prestige, or to deter or coerce the U.S. ${ }^{27)}$ In fact, the NIE report, which called attention to the nuclear missile threat after the North Korean missile test in 1998, assessed the intentions of SOCs this way-contrary to its emphasis on the threat: "North Korea, Iran, and Iraq would view their ICBMs more as strategic weapons of deterrence and coercive diplomacy than as weapons of war." ${ }^{28)}$

There is no doubt about the fact that SOCs have developed nuclear missile capabilities that can eventually hit targets in the U.S. However, if those weapons are more of a deterrence measure, then they may not be threatening to U.S. security as much as to U.S. prestige of not being threatened or U.S. capability of global power projection. In addition, if we consider our own MD options, we have to examine what kinds of missile threats we will face in the near future.

\section{Can it shoot down missiles?}

In theory, yes, but it has a long way to go to accomplish the mission. Based on the previous experiences and attempts with MD capabilities, the U.S. is currently developing MD systems capable of defending the U.S., its deployed forces, and its allies against ballistic missiles of all ranges and in all phases of flight.

By range, missiles can be grouped into four categories: short-range (less than

25) Even officials in the Bush administration frequently state that the main issue regarding North Korea's nuclear missile development is not the possibility of the usage of the probable weapons, but the possibility of their transfer to other actors.

26) Kenneth Waltz, "Missile Defenses and the Multiplication of Nuclear Weapons," in Scott D. Sagan and Waltz, The Spread of Nuclear Weapons: A Debate Renewed (New York: Norton, 2002), p.147.

27) Charles L. Glaser and Steve Fetter, "National Missile Defense and the Future of U.S. Nuclear Weapons Policy," International Security 26-1 (Summer 2001), p.56. In addition, Waltz specifies seven reasons for why countries want nuclear weapons. He understands most of them as closely related to their survival (security perception) rather than offensive motivation. For this, see Waltz (1995), pp.5-6.

28) National Intelligence Council, "Foreign Missile Developments and the Ballistic Missile Threat Through 2015: Unclassified Summary of a National Intelligence Estimate," (September 1999), p.2. 
$1,000 \mathrm{~km}$ ), medium-range (less than $3,000 \mathrm{~km}$ ), intermediate-range (less than 5,500km), and long-range (greater than 5,500km). In general, missiles have three flight phases: boost (from launch to booster burnout), midcourse (exoatmospheric flight between boost and reentry), and terminal (from reentry to hit). To accomplish the objective of the systems, the U.S. has developed three options of interception: ground-based midcourse defense (GMD), Aegis ballistic missile defense (BMD), and PATRIOT Advanced Capability 3 (PAC-3). ${ }^{29)}$ Overall, the system's capabilities are developing, continuously upgrading, and therefore raising expectations, but they are far from operationally realistic at the current stage. In other words, the system currently developing can shoot down incoming missiles but only in a very controlled situation. U.S. MD still needs flight tests under stress conditions to verify its capability and increase confidence in the models.

First of all, the GMD system has still not undergone a single meaningful test under challenging circumstances similar to a real situation. Since the Clinton administration, the U.S. has tried to deploy a GMD system and now has an initial GMD capability (11 interceptor missiles at Fort Greely, Alaska and 2 interceptor missiles at Vandenberg Air Force Base, California). The system so far has made 6 intercepts out of 11 test attempts. ${ }^{30)}$ This number seems not too bad for a system still under development. However, considering the context of the previous tests, the story has to be revised.

One of the advantages of the midcourse system is that it can have the greatest amount of time (up to 25 minutes) to locate, track, and destroy the incoming missiles. However, the system or the hit-to-kill vehicle in the system is very susceptible to decoys. ${ }^{31)}$ In the

29) Details of the U.S. MD systems are drawn from FY2006 Annual Report of the Office of the Director, Operational Test and Evaluation (DOT\&E), January 2007.

30) Victoria Samson, "Flight Tests for Ground-based Midcourse Defense (GMD) System" http://www.cdi.org/pdfs/gmd\%20ift2.pdf (September 11, 2007). On September 28, 2007, the Missile Defense Agency (MDA) conducted another successful flight intercept test of the GMD system, but the MDA insisted that the September 2006 test, which was successful in intercepting, should not be included in the overall success count. See Victoria Samson, "Missile Defense by the Numbers"

http://www.cdi.org/friendlyversion/printversion.cfm?documentID=4117\&from_page=../ program/document.cfm (November 28, 2007)

31) Actually, boost phase capture can be ideal for MD because it intercepts missiles much earlier during their flight. The heat the rocket emits when lifting a missile makes it easy to distinguish decoys from actual warheads, and the boost phase interception can even prevent decoys from being deployed. In addition, a missile's direction and course are very predictable in this phase. The only challenge with this interception is that the phase ends in a relatively short period of time, less than 5 minutes. See MDA, "Ballistic Missile Defense Challenge," MDA Fact Sheets. http://www.mda.mil/mdalink/pdf/bmdchall.pdf (September 11, 2007), pp.1-2. Therefore, although the coverage of a boost phase defense is theoretically broad, its technical constraint narrows its usage for a limited range. To be effective and applicable, a boost phase system requires forward deployment of some of the major components such as 
6 successful tests, the most recent one on September 1, 2006, used no countermeasures at all. The other 5 tests used large balloon(s) as decoys. ${ }^{32)}$ Those balloons had infrared (IR) signatures much higher than that of the mock warhead so that the kill vehicle could easily differentiate them from the target warhead. In addition, the trajectory of the warheads was known to the kill vehicle beforehand. Therefore, locating and trackingthe basic component and function of the system-were not tested in a realistic way.

The performance of the Aegis BMD system's tests is better than that of the GMD system. Aegis BMD is a highly mobile and sea based missile defense system that engages and intercepts short- and medium-range theater ballistic missiles. The system has made 8 intercepts out of ten attempts so far. ${ }^{33)}$ However, all the targets were either unitary rockets or had a single separating warhead. The system still lacks and needs flight tests using modified medium-range targets under stressing endgame scenarios such as multiple simultaneous engagements.

The PAC-3 system has made 9 intercepts out of 15 attempts in operational testing. The latest successful flight test was done on August 31, 2006. ${ }^{34)}$ The U.S. Army has already deployed PAC-3 to provide theater defense for the deployed forces against short-and intermediate-range missiles. Recent successful tests included simultaneous multiple engagements of multiple targets.

Among the above technological options, the GMD has received the majority of the funding. However, as noted above, it has not proved the probability of its successful engagement with and destruction of incoming missiles in a real situation. The tests should be conducted under realistic conditions to demonstrate the possibility. At the same time, enough tests should be conducted to provide meaningful information about the system performance to confirm its usability. ${ }^{35)}$ However, U.S. congressional support is waning and it is highly likely that part of the funding for the GMD system will be transferred to the development of other more hopeful options. This, in turn, would limit and delay further the operationalization of the GMD system.

Overall, various MD systems are awaiting more serious tests. Until the tests confirm

sensor systems including radars and interceptors to guarantee a rapid interception.

32) Samson, "Flight Tests for Ground-based Midcourse Defense (GMD) System."

33) Victoria Samson, "Flight Tests for Aegis Ballistic Missile Defense" http://www.cdi.org/pdfs/aegis\%20bmd\%20ift.pdf (September 11, 2007).

34) Victoria Samson, "Flight Tests for PATRIOT Advanced Capability (PAC)-3" http://www.cdi.org/news/missile-defense/pac_3\%20IFT.pdf (September 12, 2007).

35) Lisbeth Gronlund, David Wright, and Stephen Young, "An Assessment of the Intercept Test Program of the Ground-based Midcourse National Missile Defense System," Defense and Security Analysis 18-3 (2002), p.255. 
the capabilities of the systems to successfully engage with incoming missiles, we should not rely too much on MD when considering options to increase our national security.

\section{$\mathrm{V}$. Does it make the world more safe or reduce the possibility of war occurring?}

Maybe it does for the U.S., but raises the possibility of a new arms race. For us, the result may be different. A simple understanding of the dynamic of U.S. MD sees the system as a solution to a well-defined problem. If a defense is added, there is no reason that one will become less secure. In other words, the world for the U.S. may become safer if it acquires an effective MD capability.

However, this narrow focus fails to address broader implications of U.S. MD in international relations, at best telling us an incomplete story, and may lead to an unanticipated policy outcome. For example, in addition to possible arms races between the U.S. and its strategic adversaries (Russia and China), in theory, MD deployment may likely escalate regional conflicts to war during the course of action-reaction chains between the U.S. and its regional challengers. ${ }^{36)}$ In other words, MD may be a counterproductive policy if its international implications are not fully considered. ${ }^{37)}$

First of all, if the system works, it will increase U.S. security at least in the short run by providing a protection against a variety of missile threats. However, its strategic competitors-Russia and China-will also try to compensate for their strategic disadvantage by developing more lethal or accurate weapons in the long run. For example, as noted earlier, a U.S. surprise first strike would destroy all but a few tens of Russian warheads, and national control over those surviving weapons might be lost. ${ }^{38)}$ Then even a limited missile defense would work against Russia's severely reduced

36) Several game-theoretic analyses address this under-considered aspect of MD in the regional context. They assume that a MD-backed U.S. would take tougher approaches in dealing with regional challengers. In response, regional challengers are assumed to take collision courses by the definition of their characteristics used by the U.S. For this, see Raymond E. Franck, Jr. and Francois Melese, "The Access Deterrence Scenario: A New Approach to Assessing National Missile Defense," Defense and Security Analysis 18-3 (2002), pp.227238; Robert Powell, "Nuclear Deterrence Theory, Nuclear Proliferation, and National Missile Defense," International Security 27-4 (Spring 2003), pp.86-118; and Simon (2002).

37) Of course, this study neither argues that MD is a bad policy nor tries to prove it. The main point here is to describe why MD is inherently an international issue and how we can properly examine the dynamics behind MD based on this understanding.

38) Bruce Blair, "The Impact of National Missile Defense on Russia and Nuclear Security," Defense Monitor 29-8 (October 2000), p.2. 
surviving missiles. ${ }^{39)}$ Only if severe constraints on U.S. offensive capabilities are imposed, would U.S. MD be tolerable to Russia. ${ }^{40)}$ Otherwise, Russia will be compelled to develop and modernize its strategic weapons.

In addition, if the system works, China's less-than-25 ICBMs would no longer be an effective deterrent. China should build up its strategic strength as a deterrent. As a regional hegemon, it cannot accept a deteriorating balance shift in the region. Actually China is moving away from its "minimal deterrence" posture. For this reason, some argue that adding a defensive dimension to the already complex issues of nuclear crisis management, arms reductions, and force modernization simply complicates the issues. The system may have a negative impact on the issues; therefore, it destabilizes the world. ${ }^{411}$

Second, at the regional level, a U.S. MD is likely to increase the possibility of war. By definition, rogue states are assumed to not be afraid of going to war for some purposes. And the balance of resolve usually favors a small state whose survival is at issue vis-àvis a strong state. According to Powell, U.S. MD has a broader meaning than a simple offense-defense balance in military terms. MD would give the U.S. more freedom of action and make SOCs less likely to take a risk in a possible regional crisis. However, paradoxically, since a U.S. backed by MD will take a more aggressive stance against any regional SOCs, actually MD is likely to raise the risk of a nuclear attack on the U.S. in a confrontation with them unless MD is flawless. ${ }^{42)}$

Other game theoretical models demonstrate similar outcomes in hypothetical scenarios. For example, Franck and Melese (2003) argue that when an MD equipped U.S. confronts a state that tries to change the status quo in the region of U.S. major or vital interest, there will likely be a war in the region. Another game theory model shows that

39) In this sense, Russia would consider an extensive MD as emergent U.S. reliance on defense away from deterrence. Then, Russia would be unlikely to agree to de-alert its nuclear forces. See John Newhouse, "The Missile Defense Debate," Foreign Affairs 80-4 (2001), pp.99-100.

40) Blair (2000), p.3.

41) Stephen J. Cimbala, "Deterrence and Friction: Implications for Missile Defense," Defense and Security Analysis 18-3 (September 2002), pp.201-220. Since the relationship between the perceived or expected performance of MD and its actual capabilities is largely unknown, more subtle analyses of the friction between the two are required. Hentz also notes that since it is evident that U.S. MD is aimed at Chinese nuclear missiles, both a new arms race between the U.S. and China and the regional instability of Northeast Asia are likely. See James J. Hentz, "The Paradox of Instability and Stability: United States "Primacy", China, and the National Missile Defense (NMD) Debate," Defense and Security Analysis 19-3 (September 2003), pp. 293-299.

42) Powell (2003), pp.106-112. 
MD deployment will make regional nuclear proliferation less likely, but it will make regional conflicts more likely and more severe. ${ }^{43)}$

In a word, the effect of U.S. MD is to increase the severity of regional conflict. This is supposed to happen because MD would make the U.S. or its allies take a more aggressive path. In other words, if MD guarantees a more assertive U.S. intervention to help its allies, those allies, knowing that, can act more aggressively against their rivals in the region. ${ }^{44)}$ Ironically, MD deployment makes a rogue state less likely to acquire nuclear capabilities, but the country is more likely to escalate the crisis to war. ${ }^{45)}$

Overall suggestion from both the review of probable regional responses to U.S. MD and hypothetical scenarios is that MD may be counterproductive to regional security in Northeast Asia where historical tensions remain intact. It implies that the U.S. and its allies should be very careful in trying to make their commitments to MD and be aware of security concerns of others in the region.

\section{Concluding remarks: Should we have an MD?}

Many proponents of MD in the U.S. seem relatively unconcerned about its impact on international relations. ${ }^{46)}$ They believe MD is a domestic issue because it is designed to defend U.S. territory, not to attack any countries. However, regardless of its original purpose, it has been deeply involved in other countries' security concerns and national interests. MD politics reveals how the shadow of the security dilemma still exerts a significant influence on international relations. In addition, if we extend the discussion to a regional context, a functioning MD can easily reinforce the security dilemma already existing in the Northeast Asian region. ${ }^{47}$

U.S. experiences during the Cold War uncover some implications for the main claim of

43) Simon (2002).

44) Ibid., p.289.

45) Ibid., p.291.

46) For example, they, either intentionally or mistakenly, ignore the dynamic of the security dilemma in international relations regarding the U.S. MD. The security dilemma is supposed to affect many of the (non-cooperative and sometimes even cooperative) relations between countries.

47) Glaser notes that to reduce the impact of the security dilemma, correctly signaling a state's motive is critical. For this, see Charles L. Glaser, "The Security Dilemma Revisited," World Politics 50-1 (1997), pp.171-201. However, the current situation in Northeast Asia is pointing in a different direction that may lead to increase the uncertainty about each state's possible adversaries' motives. 
this essay. In that period, a series of MD projects were neither purely defensive measures nor limited in their effects. They were designed to advance U.S. strategic advantage over its rivals. ${ }^{48)}$ With its ability to acquire additional power elements, the U.S. constantly pursued MD. In the same vein, given the current international situation, unless there is an event that impedes the existing U.S. domestic policy consensus for the deployment of MD and establishes a new policy consensus for abandoning MD, U.S. policy toward MD may remain the same. ${ }^{49)}$

Offensive realism posits that states respond to international uncertainties by seeking more power and influence when they are able to do so, in preparation for possible future threats. The threat represents the uniqueness of international relations. Although there can be various ways to mitigate the effect of international anarchy, from the perspective of realism, security threats in international relations are inevitable and exist as a constant unless the international system itself changes. ${ }^{50)}$ For this reason, it is reasonable to say that a threat itself does not yield a specific policy outcome. Instead, power resources available to a state determine how the state acts in response to international incentives or threats.

Anyway, the U.S. is acquiring comprehensive MD capabilities and Japan is cooperating with the U.S. to deploy MD systems. The questions left for us are whether we should have an MD system and whether we have the resources to seek MD. To answer these

48) See Bong-Jun Ko, "An Offensive Defense: Missile Defense and the Nuclear Posture of the United States during the Cold War," Journal of Korean Politics 16-2 (October 2007), pp.191227 (in Korean).

49) There are two possibilities that could change this domestic policy consensus. One is altering the domestic political structure. It would be a Democratic take-over of the administration by winning the upcoming 2008 presidential election. Another possibility may come from waning confidence in MD technology. If skepticism is broadly shared by elites or the American public, the situation may be different. The repeated failure in interception tests of the current system until now leaves room for such a change in the faith in the system. Actually, the strong domestic support for the SDI declined when some of the main elements of the system proved to be impossible to achieve at the time, and most of the unpromising technologies of the SDI lost their funding by 1987. See John E. Pike, Bruce G. Blair, and Stephen I. Schwartz, "Defending against the Bomb," in Schwartz (ed.), Atomic Audit: the Costs and Consequences of U.S. Nuclear Weapons since 1940 (Washington, D.C.: Brookings Institution Press, 1998), p.291.

50) For discussions of ways to mitigate the negative effects of anarchy, see, among others, Michael W. Doyle, "Kant, Liberal Legacies, and Foreign Affairs, Part 2," Philosophy and Public Affairs 12-4 (Fall 1983), pp.205-232; Robert O. Keohane, After Hegemony: Cooperation and Discord in the World Political Economy (Princeton: Princeton University Press, 1984); Kenneth A. Oye, "Explaining Cooperation under Anarchy: Hypothesis and Strategies," World Politics 38-1 (1985), pp.1-22; and Stephen M. Walt, The Origins of Alliances (Ithaca: Cornell University Press, 1987). 
questions, we should first identify what our strategic goal is in relation with MD. The U.S. wants to win a nuclear war, if inevitable. Therefore, the U.S. has to have an MD either to secure its second strike capability or to protect against small enemy arsenals after its disarming surprise attack. Winning a nuclear war does not make any sense to us. Therefore, unlike U.S. MD, if we have our own MD, there will be room for arguing that it is purely defensive.

However, as demonstrated by the case of Japan's collaboration with the U.S., developing an effective MD system requires such highly advanced technologies and such a huge amount of money that even Japan cannot afford it alone. Of course, we do not have such domestic resources, either. That is the reality. The only possible way for us to obtain an MD capability is to be included in U.S. global MD systems as a strategic partner. We are in the middle of doing this, although we do not know the final outcome of it.

We are close to deploy two of the three BMD systems that the U.S. has developed. First, the current Roh administration has already decided to employ PAC-3 systems to defend against possible North Korean short-range missile attacks. Secondly, we will soon have Aegis shipboard systems that can employ Standard Missile (SM) 3 missiles, which are the backbone of the U.S. Aegis BMD system. Finally, we do not have any reasons to get directly involved in the U.S. GMD system. The U.S. has no plan to deploy interceptor or radar sites in Northeast Asia for the moment.

The two systems under development for us can basically increase our security by strengthening our defense. In addition, collaboration with the U.S. and probably with Japan can increase their alliance commitment to us. However, these benefits of having MD should be measured against the costs of it. Probable costs in addition to domestic resource consumption may include arms races with North Korea as well as being targeted by both Russian and Chinese strategic weapons.

To be sure, the PAC-3 system is still less than perfect and is not quite adequate in defending against the North's short-range missiles. In addition, North Korea may be fine-tuning its short-range missiles to get through the South's PAC-3 system. If we really need a defense against the North's short-range missiles, we should have an almost perfect defense because short-range missiles do not allow any second chance to intercept. Secondly, another main function of the Aegis system that we will soon launch should be to provide all short-to long-range missile threat information to U.S. Strategic Command and U.S. Pacific Command to ensure their situational awareness. Knowing this, Russia and China will become nervous by our moves. More rapid and accurate strategic information made available by the Aegis system could hurt the deterrence 
capabilities of both Russia and China.

The most likely scenario of a military exchange in Northeast Asia is the one between the U.S. and China regarding the Taiwan Strait. In such a case, there is no guarantee that China will not think of disarming nearby enemy strategic elements first. Then, our Aegis system would be one of the targets. Of course, if that military exchange escalates to a full-scale war, regardless of the Aegis system, Korea will likely be a target of Chinese attack because it is one of the major allies of the U.S. in Northeast Asia. However, it is doubtful that China will wage a full-scale war against the U.S. considering the fact that it does not have enough strategic offensive capabilities. It will likely take a selective hit strategy either to limit U.S. involvement in the Taiwan Strait and Northeast Asia or to demonstrate its resolve to win the conflict. This situation will make a big difference for us and possibly pose a bigger problem for us than for the U.S.

Overall, a Korean MD does not make any difference to the U.S. in terms of both costs and benefits. It does not make the U.S. more secure nor less secure. The problem is that, by contrast, it involves both costs and benefits for us. Now is the time to think more seriously about our strategic goals and capabilities to accomplish those goals. All the weapons development and procurement should be directed by clearly defined national strategies. One of the goals should be to maintain peace and avoid military conflicts on the Korean Peninsula.

For now, our projected MD capabilities do not seem sufficient to serve those goals adequately. Considering the fact that the U.S. MD has shown a technological potential but still entails many international security issues to deal with, we should also ponder negative effects that MD would leave to us. To avoid any unwanted outcome, we need to conduct more thorough analyses of international and regional dynamics that would be induced by our MD systems. 


\section{REFERENCES}

Art, Robert J. “To What Ends Military Power." International Security 4-4 (Spring, 1980).

Blair, Bruce G. "The Impact of National Missile Defense on Russia and Nuclear Security.” Defense Monitor 29-8 (October, 2000).

Cimbala, Stephen J. "Deterrence and Friction: Implications for Missile Defense." Defense and Security Analysis 18-3 (September, 2002).

Director of the Operational Test and Evaluation. FY2006 Annual Report of the Office of the Director, Operational Test and Evaluation (DOT\&E) (January, 2007).

Doyle, Michael W. "Kant, Liberal Legacies, and Foreign Affairs, Part 2.” Philosophy and Public Affairs 12-4 (Fall, 1983).

Eisendrath, Craig, Melvin A. Goodman, and Gerald E. Marsh. The Phantom Defense: America's Pursuit of the Star Wars Illusion. Westport: Praeger, 2001.

Franck, Raymond E. Jr. and Francois Melese. "The Access Deterrence Scenario: A New Approach to Assessing National Missile Defense.” Defense and Security Analysis 18-3 (2002).

Glaser, Charles L. “The Security Dilemma Revisited.” World Politics 50-1 (1997).

Glaser, Charles L. and Steve Fetter. "National Missile Defense and the Future of U.S. Nuclear Weapons Policy." International Security 26-1 (Summer, 2001).

Gronlund, Lisbeth David Wright, and Stephen Young. "An Assessment of the Intercept Test Program of the Ground-based Midcourse National Missile Defense System.” Defense and Security Analysis 18-3 (2002).

Haggard, Stephen and Mathew D. McCubbins, "Political Institutions and the Determinants of Public Policy," in Haggard and McCubbins. Eds. Presidents, Parliaments, and Policy. Cambridge: Cambridge University Press, 2001.

Hentz, James J. "The Paradox of Instability and Stability: United States "Primacy", China, and the National Missile Defense (NMD) Debate." Defense and Security Analysis 19-3 (September, 2003).

Jervis, Robert. "Cooperation under the Security Dilemma." World Politics 30-2 (1978).

Jervis, Robert. "The Political Effects of Nuclear Weapons: A Comment." International Security 13-2 (Fall, 1988).

Keohane, Robert O. After Hegemony: Cooperation and Discord in the World Political Economy. Princeton: Princeton University Press, 1984. 
Ko, Bong-Jun. "An Offensive Defense: Missile Defense and the Nuclear Posture of the United States during the Cold War." Journal of Korean Politics 16-2 (October, 2007) (in Korean).

Lebovic, James H. "The Law of Small Numbers: Deterrence and National Missile Defense." The Journal of Conflict Resolution 46-4 (August, 2002).

Lieber, Keir A. and Daryl G. Press. "The End of MAD? The Nuclear Dimension of U.S. Primacy." International Security 30-4 (Spring, 2006).

Lieber, Keir A. and Daryl G. Press. "The Rise of U.S. Nuclear Primacy." Foreign Affairs 85-2 (March/April, 2006).

Lieber, Keir A. and Daryl G. Press. "U.S. Nuclear Primacy and the Future of the Chinese Deterrent." China Security 3-1 (Winter, 2007).

Mearsheimer, John J. The Tragedy of Great Power Politics. New York: Norton. 2001.

Mearsheimer, John J. and Stephen M. Walt. “An Unnecessary War.” Foreign Policy 134 (Jan/Feb, 2003).

Missile Defense Agency. "Ballistic Missile Defense Challenge." MDA Fact Sheets. http://www.mda.mil/mdalink/pdf/bmdchall.pdf (September 11, 2007).

Mueller, John. "Simplicity and Spook: Terrorism and the Dynamics of Threat Exaggeration." International Studies Perspectives 6-2 (May, 2005).

Mufson, Steven. 'Threat of 'Rogue' States: Is It Reality or Rhetoric?' Washington Post (May 29, 2000). P. A01.

National Intelligence Council. "Foreign Missile Developments and the Ballistic Missile Threat trough 2015: Unclassified Summary of a National Intelligence Estimate." (September, 1999).

Newhouse, John. “The Missile Defense Debate.” Foreign Affairs 80-4 (2001).

Norris, Robert S. and Hans M. Kristensen. "Russian Nuclear Forces, 2005." Bulletin of the Atomic Scientists 61-2 (March/April, 2005).

Norris, Robert S. and Hans M. Kristensen. "Russian Nuclear Forces, 2006." Bulletin of the Atomic Scientists 62-2 (March/April, 2006).

Oye, Kenneth A. "Explaining Cooperation under Anarchy: Hypothesis and Strategies." World Politics 38-1 (1985).

Pike, John E., Bruce G. Blair, and Stephen I. Schwartz, "Defending against the Bomb," in Schwartz. Ed. Atomic Audit: the Costs and Consequences of U.S. Nuclear Weapons since 1940. Washington, D.C.: Brookings Institution Press, 1998.

Powell, Robert. "Nuclear Deterrence Theory, Nuclear Proliferation, and National Missile Defense." International Security 27-4 (Spring, 2003). 
Samson, Victoria. "Flight Tests for Aegis Ballistic Missile Defense." http://www.cdi.org/pdfs/aegis\%20bmd\%20ift.pdf (September 11, 2007).

Samson, Victoria. "Flight Tests for Ground-based Midcourse Defense (GMD) System." http://www.cdi.org/pdfs/gmd\%20ift2.pdf (September 11, 2007).

Samson, Victoria. "Flight Tests for PATRIOT Advanced Capability (PAC)-3." http://www.cdi.org/news/missile-defense/pac_3\%20IFT.pdf (September 12, 2007).

Simon, Michael W. "Rogue State Response to BMD: The Regional Context." Defense and Security Analysis 18-3 (2002).

The Stockholm International Peace Research Institute, The SIPRI Military Expenditure Database. http://first.sipri.org/non_first/milex.php (September 10, 2007).

Tsebelis, George. Veto Players: How Political Institutions Work. Princeton: Princeton University Press, 2002.

U.S. Department of Defense, Nuclear Posture Review of 2001.

Van Evera, Stephen. Causes of War: Power and the Roots of Conflict. Ithaca: Cornell University Press, 1999.

Walt, Stephen M. The Origins of Alliances. Ithaca: Cornell University Press, 1987.

Waltz, Kenneth. "Missile Defenses and the Multiplication of Nuclear Weapons," in Scott D. Sagan and Waltz. The Spread of Nuclear Weapons: A Debate Renewed. New York: Norton, 2002.

Waltz, Kenneth. Peace, Stability, and Nuclear Weapons, Policy Paper 15, University of California Institute on Global Conflict and Cooperation. La Jolla. CA: IGCC. 1995.

Waltz, Kenneth. Theory of International Politics. Reading. MA: Addison-Wesley, 1979.

White House. "Remarks by the president on National Missile Defense" (December 13, 2001). http://www.whitehouse.gov/news/releases/2001/12/20011213-4.html (September 10, 2007).

White House. The National Security Strategy of the United States of America (September, 2002). 